\title{
The Application of SPSS in Analyzing the Effect of English Vocabulary Strategy Instruction
}

\author{
Shaoying Chen \\ College of Foreign Languages, Northeast Forestry University, Harbin 150040, China \\ E-mail: chenshaoying33@yahoo.com.cn
}

\begin{abstract}
The vocabulary learning is one of very important part in the college English teaching. Correct analysis of the result of vocabulary strategy instruction can offer feedbacks for English teaching, and help teachers to improve the teaching method. In this article, the issue how to use SPSS (Statistical Package for the Social Science) to scientifically statistically analyze the vocabulary test achievements is discussed, and the research result can offer instructive feedback opinions for the vocabulary teaching.
\end{abstract}

Keywords: Vocabulary learning strategy, SPSS, Teaching method

With the development of the information technology, the integration of education measurement and information technology is becoming into a trend. College English teachers should not only grasp large numerous of basic knowledge about learning strategy, but possess the ability to statistically analyze and explain the application result of learning strategy. Only with the skills of statistical analysis and explanation, they can correctly describe and explain the application result of learning strategy in the teaching, and put forward instructive opinions for the teaching on the macro level.

SPSS (designed and developed by American Chicago Professional Software Corporation) is not only the professional statistical software, but an instrument with powerful function and convenient operation for teachers to implement and study the language teaching ( $\mathrm{Su}, 2002)$. At present, many scholars have made large numerous attempts and practices, such as Huangpu Wei's "Application of SPSS Correlative Analysis and Linear Regression Analysis in the Analysis of English Test Achievements" (Huangpu, 2007), Liu Baoquan \& Xi, Zhong'en's “Analyzing English Language Test with SPSS” (Liu, 2004), and Hu Chan's "How to Analyze an English Testing with SPSS" (Hu, 2003).

In the teaching of English vocabulary, when students' vocabulary learning strategy is cultivated, the vocabulary test achievements are scientifically and statistically analyzed by SPSS, and the application effect of the vocabulary learning strategy is analyzed.

\section{Experimental method}

The object of the experimental research includes two teaching classes of freshmen of non-English major, and one if the experimental class and the other is the control class. Teachers teach these two classes for one term, and implement different vocabulary strategy cultivation plans in the English teaching process. In the control class, the traditional vocabulary teaching mode including reading words (students), explaining (teachers) regular collocation and example sentences is adopted. And in the experimental class, the teaching mode mainly cultivating and using the vocabulary strategy is adopted, i.e. reading words (students), explaining different vocabulary strategies according to different characters of vocabularies such as grouping strategy, association strategy, guessing word strategy. Except for different vocabulary teaching modes, the materials and complementary materials used in the experimental class and the control class are same completely, and students in two classes periodically (one time monthly, four times together) accept the vocabulary test with same testing questions and time.

After the teaching experiment ends, students' names and vocabulary test achievements are filled in tables, and analyzed by SPSS according to the principle of paired-sample $t$ test. The analysis process of SPSS can be described as follows: leading prepared data into SPSS software, selecting the "Compare Means $\rightarrow$ Single Paired-Sample T Test" on the Analyze mina menu, taking the vocabulary test achievements of the experimental class and the control class as the "Paired-variables", Clicking [Options...], and "Paired-Sample T Test" occurs: input 95 to the dialog box of "Options", so the level of selecting mean is 0.05 , then clicking "confirming" to process the data.

\section{Experimental result and analysis}

Analyze the English vocabulary test achievements by SPSS, and obtain the result of paired-sample T test of the experimental class and the control class, and each paired sample $\mathrm{T}$ test result has same form of table, and Table 1 
and Table 2 are the paired sample $\mathrm{T}$ test result of the third vocabulary test achievements of the control class and the experimental class.

Table 1 is the paired sample statistics, where, Mean is the average achievement, $\mathrm{N}$ is the amount of sample, Std. Deviation is the standard deviation, Std. Error Mean is the standard deviation of the average achievement.

Table 2 is the paired sample test, where, Paired Differences is the paired sample difference, Mean is the average value of the paired sample difference, Std. Deviation is the standard deviation of paired samples, Std. Error Mean is the standard deviation of the averages of paired samples, 95\% Confidence Interval of the Difference is the confidence interval of the average of the paired sample difference under the confidence level of $95 \%$, Lower is the lower bound of the interval, Upper is the upper bound of the interval, $t$ is the $t$ statistic of test, $d f$ is the degree of freedom, and Sig. (2-tailed) is the meaning value of the two-tailed test, i.e. the value of P.

In order to analyze the achievements of 4 times vocabulary tests more clearly, summarize and compare key parameters such as Mean, Std. Deviation, $\mathrm{T}$ value, $\mathrm{P}$ value in the tables, and the concrete parameters are seen in Table 3.

From Table 3, the results of the first test and the second test show that the experimental class has higher average achievements $(11.0682>10.7273,11.1136>9.2955)$, standard deviation $(5.17776>4.33677$ and $6.14255>4.43846)$, but the values of $\mathrm{P}$ of two classes are all bigger than 0.05 , that indicates that the vocabulary achievements of two classes have no significant difference after two months' vocabulary learning. The experimental result indicates that the vocabulary strategy cultivation can not obviously promote students' English vocabulary learning in short term, which may be because that the application time of vocabulary strategy is short and students can not grasp it masterly.

But in the tests of the third month and the fourth month, the average and standard deviation of the achievements of the experimental class are all higher than the control class, and the $\mathrm{P}$ values of the experimental class and the control class are all far less than 0.05, which indicates the test results of two classes have significant difference. The difference shows that students' ability of vocabulary learning in the experimental class has been enhanced obviously after long-term vocabulary strategy learning.

\section{Conclusions}

In the teaching of English vocabulary, when students' vocabulary learning strategy is cultivated, the vocabulary test achievements are scientifically and statistically analyzed by SPSS, and the application effect of the vocabulary learning strategy is analyzed in the article. The research result indicates that the software of SPSS could correctly analyze the teaching effect of vocabulary strategy instruction in practical application, and the application of SPSS should be fully pushed in study of the foreign language teaching science to make it be the powerful assistant instrument for foreign language teaching researchers.

\section{References}

Huangpu, Wei. (2007). Application of SPSS Correlative Analysis and Linear Regression Analysis in the Analysis of English Test Achievements. China Electric Power Education. No.10.

$\mathrm{Hu}$, Chan. (2003). How to Analyze an English Testing with SPSS. Journal of Xianning Teachers College. No.1.

Liu, Baoquan \& Xi, Zhong'en. (2004). Analyzing English Language Test with SPSS. ETFLT Educational Technology for Foreign Language Teaching. No.1.

Su, Jinming. (2002). Application Practice of SPSS Series. Beijing: Electronic Industry Press.

Table 1. Statistics of paired samples

\begin{tabular}{|c|c|c|c|c|}
\hline & Mean & N & Std. Deviation & Std. Error Mean \\
\hline Experimental class & 12.2955 & 44 & 4.75238 & .357 \\
\hline Control class & 9.4091 & 44 & 4.19478 & .357 \\
\hline
\end{tabular}


Table 2. Paired samples test

\begin{tabular}{|c|c|c|c|c|c|c|c|c|c|}
\hline & & \multicolumn{5}{|c|}{ Paired Differences } & \multirow[t]{2}{*}{$\mathrm{t}$} & \multirow[t]{2}{*}{$\mathrm{df}$} & \multirow[t]{2}{*}{$\begin{array}{c}\text { Sig. } \\
\text { (2-tailed) }\end{array}$} \\
\hline & & \multirow[t]{2}{*}{ Mean } & \multirow[t]{2}{*}{$\begin{array}{c}\text { Std. } \\
\text { Deviation }\end{array}$} & \multirow[t]{2}{*}{$\begin{array}{c}\text { Std. Error } \\
\text { Mean }\end{array}$} & \multicolumn{2}{|c|}{$\begin{array}{l}95 \% \text { Confidence } \\
\text { Interval of the } \\
\text { Difference }\end{array}$} & & & \\
\hline & & & & & Lower & Upper & & & \\
\hline Pair 1 & $\begin{array}{c}\text { Experime } \\
\text { ntal class } \\
\& \text { Control } \\
\text { class }\end{array}$ & 2.88636 & 6.33637 & .95524 & .95993 & 4.81280 & 3.022 & 43 & .004 \\
\hline
\end{tabular}

Table 3. Descriptive statistics of vocabulary tests

\begin{tabular}{|c|c|c|c|c|c|c|}
\hline \multirow[b]{2}{*}{ Times } & \multicolumn{2}{|c|}{ Mean } & \multicolumn{2}{|c|}{ Std. Deviation } & \multirow[b]{2}{*}{ t-test } & \multirow[b]{2}{*}{$\begin{array}{c}\text { Sig. } \\
\text { (2-tailed) }\end{array}$} \\
\hline & $\begin{array}{c}\text { Experimental } \\
\text { Class }\end{array}$ & $\begin{array}{c}\text { Control } \\
\text { Class }\end{array}$ & $\begin{array}{c}\text { Experimental } \\
\text { Class }\end{array}$ & $\begin{array}{c}\text { Control } \\
\text { Class }\end{array}$ & & \\
\hline 1 & 11.0682 & 10.7273 & 5.17776 & 4.33677 & .348 & .729 \\
\hline 2 & 11.1136 & 9.2955 & 6.14255 & 4.43846 & 1.1519 & .136 \\
\hline 3 & 12.2955 & 9.4091 & 4.75238 & 4.19478 & 3.022 & .004 \\
\hline 4 & 8.6364 & 3.7898 & 5.08802 & 2.60140 & 5.529 & .000 \\
\hline
\end{tabular}

